\title{
The Diversity of Adversities with Psychometric Properties Assessment across Youth Categories through Rasch Model
}

La diversidad de adversidades con evaluación de propiedades psicométricas en categorías juveniles a través del modelo Rasch

\author{
Mohd Effendi Ewan Mohd Matore* \\ Universiti Kebangsaan Malaysia - Malaysia \\ effendi@ukm.edu.my \\ Tengku Elmi Azlina Tengku Muda** \\ Universiti Kebangsaan Malaysia - Malaysia \\ elmiazlina@ukm.edu.my
}

\begin{abstract}
This study will be focusing on several aspects such as the pattern of items distributions of adversities across youth categories, the pattern in reliability and separation index of the items and persons in measuring adversities across youth categories, the pattern in category probability curves across youth categories, and the pattern in item unidimensionality across youth categories. The research was provided empirical evidences on psychometric assessment of newly developed adversity measurement using modern psychometric theory. This information is valuable to expanding research on youth specifically in differentiating responses based on demographic profiles.
\end{abstract}

Keywords: adversity, Rasch Model, psychometric, youth, diversity, pattern.

\section{RESUMEN}

Este estudio se centrará en varios aspectos, como el patrón de distribución de elementos de las adversidades en las categorías juveniles, el patrón en la confiabilidad y el índice de separación de los elementos y las personas en la medición de las adversidades en las categorías juveniles, el patrón en las curvas de probabilidad de categoría en las categorías juveniles, y el patrón en la unidimensionalidad del ítem entre las categorías juveniles. La investigación proporcionó evidencias empíricas sobre la evaluación psicométrica de la medición de la adversidad recientemente desarrollada utilizando la teoría psicométrica moderna. Esta información es valiosa para expandir la investigación sobre la juventud específicamente en la diferenciación de respuestas basadas en perfiles demográficos.

Palabras clave: adversidad, modelo Rasch, psicométrico, juventud, diversidad, patrón. 


\section{INTRODUCTION}

The issue of youth development is crucial as Malaysia has a total of 14.7 million youths, 46 percent of its 31.7 million population based on Department of statistics Malaysia in 2015 and continuously increasing. This shows that almost half of the population in Malaysia is youth. Youth development is an important issue in national development. Youth are an important asset of the country in which they are the largest contributor to improve the living standards either from the economic, social or political aspects. The Youth Societies and Youth Development Act 2007 (Act 668) define youth as individuals between the ages of 15 to 40 years. However, in 2015, the Malaysia Youth Policy (MYP) changed the youth age limit definition to individuals between the ages of 15 years and before reaching the age of 30 years. In an increasingly competitive global environment, Malaysian youth are faced with various challenges. It is anticipated that youth challenges will multiply in the future if not properly managed (Institut Penyelidikan Pembangunan Belia Malaysia (IYRES), 2016). Malaysia Youth Policy (Ministry of Youth and Sports Malaysia, 2015) had identified four major challenges facing Malaysian youth namely politic, economy, social and technology.

While the Malaysian Youth Index (MYI) was built in 2015, item assessment was only demonstrated through reliability of item indices alone without considering psychometric testing of challenge items from MYP. The development of adversities item amongst youth is important to ensure that dominant adversity can be identified for the purpose of empowering youth or specifically by the youth age category. In addition to the general definition of youth in general from 15 to 29 , youths are also categorized into three; namely early youth which categorized under 15-18 years old, mid youth for 19-24 years old, and end youth for 25-30 years old (Institut Penyelidikan Pembangunan Belia Malaysia (IYRES), 2016). Additionally, the psychometric item testing using modern measurement theory is believed to provide more empirical information than Classical Test Theory (CTT). One of the modern theories is Rasch measurement model. Rasch model is very popular and been extensively applied in numerous fields, especially in psychology and education assessment specifically on cognitive or achievement level (Azrilah Abdul Aziz, Mohd Saidfudin Masodi, \& Azami Zaharim, 2013). However, the lacking part on the research towards psychometric properties for the items measuring adversity are very limited especially on how to see the items responded across group of different youth. The items are newly developed and this is a good effort to investigating how different response will give different impact on item functionality.

This study will be focusing on several aspects such as the pattern of items distributions of adversities across youth categories, the pattern in item and person reliability also separation index for measuring adversities across youth categories, the pattern in category probability curves across youth categories, and the pattern in item unidimensionality across youth categories.

\section{LITERATURE REVIEW}

\section{What is adversity?}

Adversity or challenges is connected with problems or obstacles experienced by an individual. The examples of challenges such as hardships, difficulties, challenge, unlucky, sadness, misery, distress and sources of stress. Stoltz and Weihenmayer (2010) categorized challenges into inner and outer adversity. The examples for inner adversity such as anxiety, loneliness, fear, lack of confidence, and depression. The external or outer adversity examples such as failure in examinations, computer breakdown, friends fighting and economic problems. For this research context, adversities or challenges among youth are based on Malaysia Youth Challenges.

\section{Youth major challenges}

Malaysia Youth Challenges has outlined four key indicators of the politic, economic, social and technology domain (Indeks Belia Malaysia, 2015; Institute for Youth Research Malaysia (IYRES), 2016). Table 1 shows a specific indicator for each domain. This indicator is defined operationally in the context of the research.

\section{Table 1. List of indicators for Malaysia Youth Challenges}

\begin{tabular}{|l|l|l|}
\hline Domain & & \\
\hline Political & P1 & Political literacy \\
\hline & P2 & Political Maturity \\
\hline & P3 & Leadership \\
\hline & P4 & Global Thinking \\
\hline & P5 & Regional and International Relations \\
\hline Economy & E1 & Cost of Living \\
\hline & E2 & Entrepreneurship Culture \\
\hline & E3 & Skills \\
\hline & E4 & Employment \\
\hline & E5 & Urban Poor Youth \\
\hline & E6 & Remigration \\
\hline & E7 & Personal financial \\
\hline & S1 & Education \\
\hline & S2 & Social Problems \\
\hline & S3 & Spirituality and Religion \\
\hline & S4 & Good Values \\
\hline & S5 & Self-identity and Unity \\
\hline & S6 & Volunteerism \\
\hline & S7 & Mental and Physical Well-being \\
\hline & S8 & Family Institution \\
\hline & & \\
\hline & &
\end{tabular}




\begin{tabular}{|l|c|l|}
\hline & S9 & Human Touch \\
\hline & S10 & Community Institution \\
\hline Technology & T1 & Information and Communication Technology \\
\hline & T2 & Social or Digital Media \\
\hline & T3 & Innovation and Creativity \\
\hline & T4 & Science and Technology \\
\hline
\end{tabular}

\section{Rating Scale Model (RSM)}

The RSM is an extension of the dichotomous model in terms of the case in which items have more than two response categories such as Likert scales. In this research, every item has four choices of response ( Likert 1 represents "not at all a problem", $2 \mathrm{r}$ represents "minor problem", 3 represents "moderate problem", and 4 represents "serious problem"). This four response will be having three thresholds. Each item threshold (k) has its own difficulty estimate (F). This estimate is modelled as the threshold at which a person has a 50/50 likelihood of choosing one category over another (Bond \& Fox, 2015) as shown in Equation (1).

Where, $\quad P_{i}=\frac{\exp \left[\beta_{n}-\left(\delta_{i}+\tau_{k}\right)\right]}{1-\exp \left[\beta_{n}-\left(\delta_{i}+\tau_{k}\right)\right]}$

$P_{i}=$ probability of getting a correct answer for Item $i$

${ }_{n}=$ ability parameter for respondent $n$

$=$ difficulty parameter of an item $i$

$k=\mathrm{k}_{\mathrm{th}}$ threshold

Item difficulty parameter means the ratio of the number of students who answer wrongly. Respondent's ability parameter is basically calculated based on the ratio of the number of correct items. Both parameters is directed through calibration. The responses for each item is transformed into equal interval score call 'measure' using natural $\log (\ln )$. The measure is in logits unit. Some of the researchers show their interests in evaluating items based on Rasch concept (Mohd Effendi Ewan Mohd Matore, 2019a, 2019b; Mohd Effendi Ewan Mohd Matore \& Ahmad Zamri Khairani, 2018; Mohd Effendi Ewan Mohd Matore, Ahmad Zamri Khairani, Siti Mistima Maat, Nor Adila Ahmad, \& Effa Rina Mohd Matore, 2018)

It has four research questions in this research.

a) What is the pattern of items distributions of adversities across youth categories?

b) What is the pattern in reliability and separation index in measuring adversities across youth categories?

c) What is the pattern in category probability curves across youth categories?

d) What is the pattern in item unidimensionality across youth categories?

\section{METHODOLOGY}

The quantitative approach has been applied with survey because of its capability to collect the data and clarify the phenomena in research. The self-administered online survey was used because cheap, no copying surveys cost of printing, and no coding needed. Thus, the results are being ready for proceed to statistical analysis (Gay \& Mills, 2018). The data collection using an online survey was conducted and required the participants to respond to all items and prohibited the possibility of missing data. The total of respondents are 500 youth with 250 (50\%) for each group of males and females The respondents were into range of 15 to 29 years old who categorized by 200 youth (40\%) from early youth category, 150 youth (30\%) represented mid youth and 150 youth (30\%) from end youth. Subjects were chosen from five zones by convenient sampling which 100 respondents represented by South, East, West, North and Borneo. The convenient sampling applied with 100 respondents were chosen from five zones (South, East, West, North and Borneo). They respondents were selected based on the sample appropriateness, and willingness to participate in this study. The characteristics of the respondents are (1) they are still within the age of youth categories (15 to 30 years old); (2) willing to answer the questionnaires items and participate; and (3) able to answer items through the medium of online. Participations also was strictly voluntary and anonymous.

Malaysian Youth Challenges model from Ministry of Sports and Youth was applied to the instrument. It has four main domain challenges comprising (a) Political (Political Maturity, Political literacy, Global Thinking, Leadership, Regional and International Relations), (b) Economy (Cost of Living, Entrepreneurship Culture, Employment, Skills, remigration, Urban Poor Youth, and personal financial), (c) Social (Education, Social Problems, Spirituality and Religion, Good Values, Self-identity and Unity, Volunteerism, Mental and Physical Well-being, Family Institution, Human Touch, and Community Institution), (d) Technology (Information and Communication Technology, Social or Digital Media, Innovation and Creativity, and Science and Technology) (Institut Penyelidikan Pembangunan Belia Malaysia (IYRES), 2016). The items are coded from 1 to 10 (politics), 11 to 24 (economy), 25 to 44 (social) and 45 to 52 (technology) with the total number of items is 52 .

The instrument is based on four Likert scales by seriousness of the problems which measure from not at all a problem (1) until serious problem (4) (Vagias, 2006). The respondents had been given one week for finishing answer the items. The data will transformed from mean score to logit using Rasch (Wright, 1993). The lower logit score show 
that the items are easier to endorse by the respondents and the higher logit show the items are harder endorsing the items.

\section{RESULT AND DISCUSSION}

This section will elaborate some aspect of Rasch psychometric elements across youth categories (early, mid and end youth). The results will be emphasizing on item distributions of dominant adversities, the pattern of items and persons reliability and separation index of the in measuring adversities, the pattern of category probability curves and item unidimensionality.

\section{Result 1: What is the pattern of items distributions of adversities across youth categories?}

The profile of items distributions have been categorized using Tukey's Hinges as shown in Table 2. The items will be categorized into quartile. The Tukey's Hinges values are not interpolated slightly, they are approximations that can be obtained with little calculation. The cutting score in this research will be at $75^{\text {th }}$ percentile or first quartile for the adversities among youth (dominant adversity). The higher logits value shows the item is hard to be endorsed by respondents and assumed as adversity.

\section{Table 2. Item distributions of adversities across youth categories}

\begin{tabular}{|c|c|c|c|}
\hline & \multicolumn{3}{|c|}{ Percentiles (Tukey's Hinges) } \\
\hline Types of youth & $\mathbf{2 5}$ & $\mathbf{5 0}$ & $\mathbf{7 5}$ \\
\hline Early youth & -.6050 & -.0200 & .5600 \\
\hline Mid youth & -.6550 & -.0550 & .5200 \\
\hline End youth & -.3200 & -.0350 & .2950 \\
\hline
\end{tabular}

Table 3 indicated that the economy is the dominant construct for early and mid-youth. The politics is the most dominant construct for end youth. In terms of the total of adversities, the combination for early youth is (Economy-Politics-Social), mid youth (Economy-Social-Politics), and end youth (Social-Politics-Economy). It means that economy dominated by two groups of youth which are early and mid-youth.

The economy covers seven major aspects in Malaysian Youth Challenges model, for example entrepreneurship culture, cost of living, urban poor youth employment, and skills. This shows that Malaysian youth have difficulty in the aspects such as financial management and debt burden, lack of cultivating entrepreneurial culture, weak manpower skilled, unemployment and marketability, limited work opportunities, competition and cost of living, urbanization problems for employment and management of personal finances. In Malaysia, youths have financial management problems such as bankruptcy. Previous studies have discussed about bankruptcy factors among youths. Youths are likely to become depressed and unable to manage financially well because of the rising cost of living. Malaysia Department of Insolvency statistics from 2005 to 2012 recorded 243,823 people declared bankruptcy. 57 percent comprise of those under age 45. The total of 50 percent of these groups are credit card holders under the age of 30 (Nurauliani Jamlus Rafdi, Noor Aimi Mohamad Puad, Wan Shahdila Shah Shahar, Fadilah Mat Nor, \& Wan Shazlinda Shah Shahar, 2015). Furthermore, it shows the evident that most of the youths are bankrupt because of the burden of serious debt obligations such as credit cards, car loan purchases and personal loans. Recent studies have put highlighting on financial literacy and decision making issues concerning colleges and universities students (Rubayah Yakob, Hawati Janor, \& Nur Ain Khamis, 2015). Youths are faced with the changing economic and financial environment in line with more complex system and financial transformation including education or personal finance loans, and education investments.

Table 3. Type of dominant adversities across youth categories based on rank

\begin{tabular}{|c|c|c|c|c|c|c|c|c|}
\hline \multicolumn{3}{|c|}{ Early youth } & \multicolumn{3}{c|}{ Mid youth } & \multicolumn{3}{c|}{ End youth } \\
\hline Entry & Measure & $\begin{array}{c}\text { Adversity } \\
\text { Type }\end{array}$ & Entry & Measure & $\begin{array}{c}\text { Adversity } \\
\text { Type }\end{array}$ & Entry & Measure & $\begin{array}{c}\text { Adversity } \\
\text { Type }\end{array}$ \\
\hline $\mathbf{2 4}$ & 1.98 & Economy & 24 & 1.65 & Economy & 5 & 0.95 & Politics \\
\hline $\mathbf{2 2}$ & 1.44 & Economy & 4 & 1.27 & Politics & 22 & 0.91 & Economy \\
\hline $\mathbf{4}$ & 1.40 & Politics & 22 & 1.25 & Economy & 24 & 0.91 & Economy \\
\hline $\mathbf{5}$ & 1.31 & Politics & 5 & 1.11 & Politics & 11 & 0.73 & Economy \\
\hline $\mathbf{3 0}$ & 1.20 & Social & 35 & 1.09 & Social & 30 & 0.73 & Social \\
\hline $\mathbf{3 5}$ & 1.03 & Social & 30 & 0.85 & Social & 3 & 0.63 & Politics \\
\hline $\mathbf{3 9}$ & 1.03 & Social & 41 & 0.76 & Social & 4 & 0.63 & Politics \\
\hline $\mathbf{4 1}$ & 0.94 & Social & 17 & 0.66 & Economy & 35 & 0.47 & Social \\
\hline $\mathbf{7}$ & 0.85 & Politics & 19 & 0.64 & Economy & 19 & 0.43 & Economy \\
\hline $\mathbf{3}$ & 0.67 & Politics & 33 & 0.52 & Social & 33 & 0.43 & Social \\
\hline $\mathbf{1 7}$ & 0.67 & Economy & 3 & 0.52 & Politics & 38 & 0.34 & Social \\
\hline $\mathbf{1 1}$ & 0.61 & Economy & 11 & 0.52 & Economy & 40 & 0.34 & Social \\
\hline $\mathbf{3 3}$ & 0.60 & Social & 23 & 0.52 & Economy & 39 & 0.32 & Social \\
\hline & & & 39 & 0.52 & Social & & & \\
\hline
\end{tabular}

Result 2: What is the pattern in reliability and separation index for measuring adversities across youth categories?

Table 4 display four criteria's for reliability and separation index including person and item reliability, person and item separation index and Cronbach Alpha. The person and item reliability were recorded within the range of 0.86 to 0.90 (for person) and 0.91 to 0.98 (for item). This value is acceptable as suggested by Bond \& Fox (2015). The Cronbach's 
alpha value recorded a reliability value of within the range of 0.88 to 0.90 and this value considered good (Fisher, 2007).

Table 4. Reliability and separation index across youth categories

Criteria/youth category
Person Reliability
Item Reliability
Cronbach Alpha
Person Separation
Item Separation

Early youth
0.90
0.98
0.90
2.99
6.27

Mid youth
0.88
0.96
0.89
2.70
4.94

End youth
0.86
0.91
0.88
2.49
3.22

The person reliability show that the items are capable to differentiate between one individual to another for a given measured variable (Bond \& Fox 2015; Wright \& Masters 1982). The high reliability of persons or items means that there is a high probability that persons (or items) estimated with high measures actually do have higher measures than persons or items assessed with low measures. Person separation is purposely to classify people and item separation is useful to validate the item hierarchy. The results show that value is more than two as suggested by Bond \& Fox (2015). For person separation, it shows that items might be sensitive to discriminate concerning high and low performers. Sufficient item separation suggests that the person sample is huge enough to endorse the item difficulty hierarchy (or called construct validity). For the separation index, it shows three levels of person abilities and four to seven levels of items difficulty. (Linacre, 2012). Figure 1 visually show that early youth respondents have the best results in fulfilling the Rasch needs of reliability and separation index.

For overall items assessment, the results show items reliability was recorded 0.99 and it is consider excellent (Fisher, 2007). The person reliability is 0.88 . The reliability value located within range of 0.81 to 0.90 and consider good (Fisher, 2007). High reliability of persons and items means that there is a high likelihood that persons or items estimated with high measures actually do have higher measures than persons or items estimated with low measures (Linacre, 2012). The Cronbach's Alpha value recorded a reliability of 0.89 and this value considered acceptable and fulfill the internal consistency (Hair, Celsi, Oritinau, \& Bush, 2017). The item separation index of 8.35 is consider excellent and person separation index is 2.75 and consider as fair (Fisher, 2007). Separation index shows three levels of person abilities and nine levels of items difficulty.

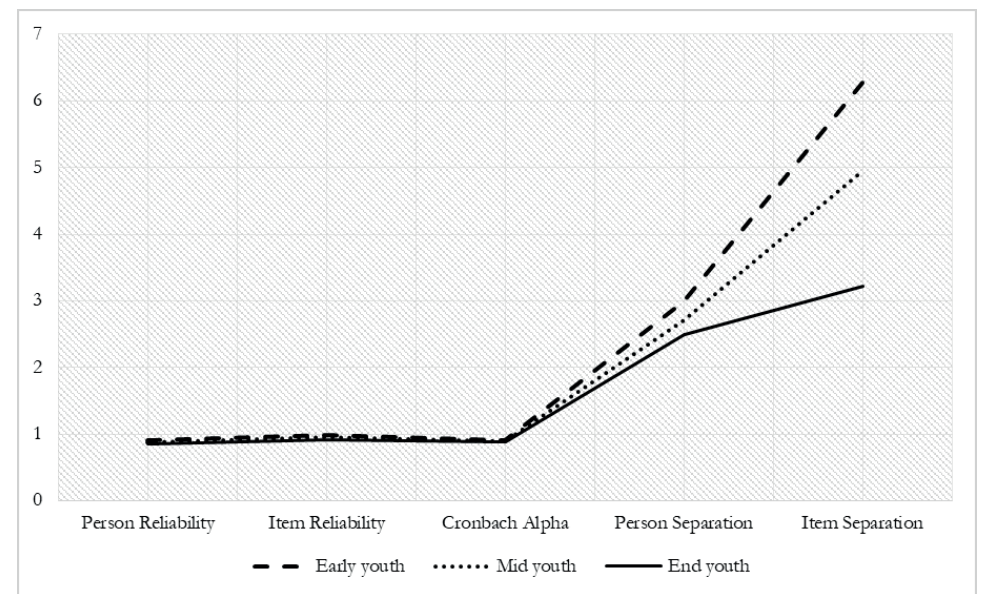

Figure 1. The visual comparison of reliability and separation index across youth categories

\section{Result 3: What is the pattern in category probability curves across youth categories?}

The category probability curves displays the likelihood of observing each ordered category based on Rasch model. The probability of each category is shown when there are more than two categories. The intersection points of nearby categories are called by Rasch-Andrich thresholds or structure calibrations. It has four likert scale in this research as mentioned. These connected directly to category likelihoods. The likelihoods associated to the probability of a observed category, not to the essential order categories of achievement. The pattern shows that every point has obviously shown its curves across youth category. The results also revealed that the curve at point 3 may show the gaps is smaller than the rest of the point.

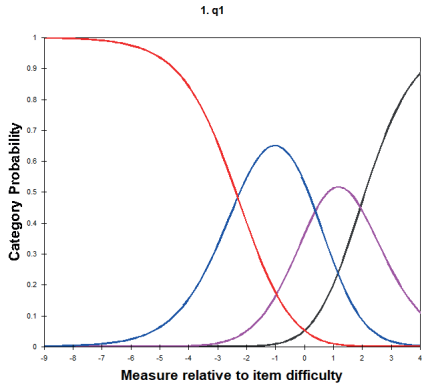

Early youth

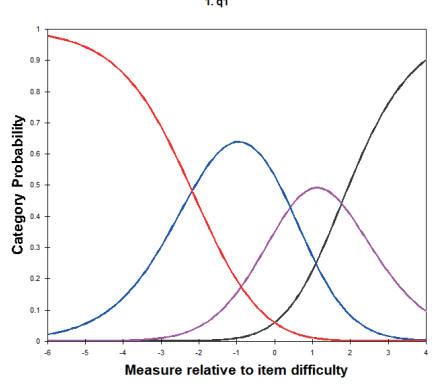

Mid youth

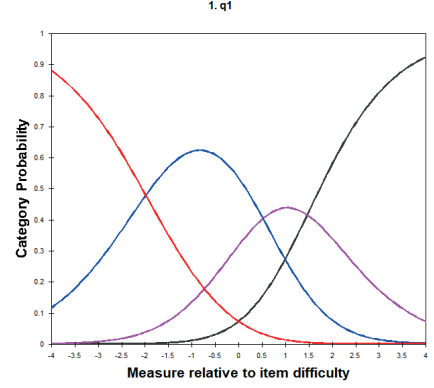

End youth 
Figure 2. The visual pattern of category probability curves across youth categories

\section{Result 4: What is the pattern in item unidimensionality across youth categories?}

Table 4 shows the aspect of unidimensionality was scrutinized using the Rasch Principal Components Analysis (PCA). The revealed that raw variance explained by measure is in range $19.3 \%$ to $29.5 \%$. Even the respond from end youth respondents stated result less than requirement, the result can consider fulfil the at least 20 percents (Reckase, 1979). The noise level of items are in the range 5.6 to $7.9 \%$ which is less than $10 \%$ as a sufficient indicator for unidimensionality (Eakman, 2012; Fisher, 2007; Linacre, 2007). The eigenvalues indicated the range of 4.1 to 5.1. It was a sign that the value less than 5.0 show the second dimension is not exist (Linacre, 2005) except for end youth. In addition, the ratio of raw variance explained by items with the unexplained variance in 1 st contrast been analysed. The ratio must be more than 3:1 and consider as acceptable (Embretson \& Reise, 2000). Two groups of early and mid-youth are more than three except for end-youth with less than two. Based on the data in Table 4, it can be concluded that the item unidimensionality was not fulfil Rasch requirement among end-youth respondents compare to early and mid-youth. The items were best measure adversities for early youth, followed by mid and end-youth.

\section{Table 5. The comparison of unidimensionality across youth categories}

\begin{tabular}{lccc}
\multicolumn{1}{c}{ Criteria/youth category } & Early youth & Mid youth & End youth \\
Raw variance explained by measures & $29.5 \%$ & $26.2 \%$ & $19.3 \%$ \\
Raw variance explained by items & $22.8 \%$ & $20.9 \%$ & $15.3 \%$ \\
Unexplained variance in 1st contrast & $5.6 \%$ & $6.5 \%$ & $7.9 \%$ \\
Eigen value & 4.1 & 4.6 & 5.1 \\
Ratio & 4.07 & 3.22 & 1.93
\end{tabular}

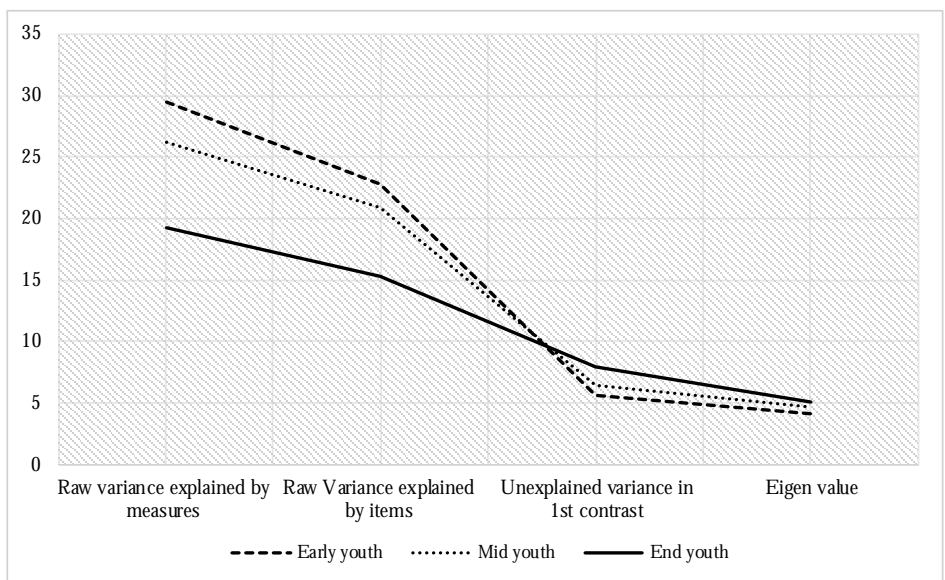

Figure 2. The visual comparison of unidimensionality across youth categories

\section{CONCLUSION}

The finding revealed that economy was the most dominant adversity among youth in Malaysia and technology is the weakest domain. The psychometric pattern shows good measurement properties such as reliability, unidimensionality and visual scale revision. Items were found to work best for early youth groups, followed by mid youth and end youth. Suggestions for improvements can be made are through the help of the youth on prudent financial management to avoid financial burdens. The items also can be improved by exploring more adversities through qualitative approach. This research also can be expanded to different and specific settings such as at schools and working youth. Further research can be done through the financial management courses to all ages for expose them with the right techniques and awareness of their savings. The limitation of this study is the adversity applied was limited. These types of challenges can be strengthen by adapting other adversities models rather than model used in Malaysia only. Further study can be done through different pattern of psychometric properties assessment according to demographic characteristics.

\section{ACKNOWLEDGMENT}

This research was supported by the Universiti Kebangsaan Malaysia under grant of GGPM-2017-088 and UKM PPFPEND-2019. 


\section{BIBLIOGRAPHIC REFERENCES}

Azrilah Abdul Aziz, Mohd Saidfudin Masodi, \& Azami Zaharim. (2013). Asas model pengukuran Rasch: pembentukan skala dan struktur pengukuran. Bangi: Penerbit UKM.

Bond, T. G., \& Fox, C. M. (2015). Applying the Rasch model: fundamental measurement in the human sciences. New Jersey: Routledge.

Eakman, A. M. (2012). Measurement characteristics of the engagement in meaningful activities survey in an agediverse sample. The American Journal of Occupational Therapy, 66(2), 20-29. https:/doi.org/10.5014/ ajot.2012.001867.

Embretson, S. E., \& Reise, S. P. (2000). Item response theory for psychologists. Mahwah, New Jersey: Lawrence Erlbaum Associates.

Fisher, J. W. P. (2007). Rating scale instrument quality criteria. Rasch Measurement Transactions, 21(1), 1095.

Gay, L. R., \& Mills, G. E. (2018). Educational research: competencies for analysis and applications (12th ed.). Upper Saddle River, New Jersey: Merrill Prentice Hall.

Hair, J. F., Celsi, M. W., Oritinau, D. J., \& Bush, R. P. (2017). Essentials of marketing research (4th ed.). New York: McGraw Hill.

Indeks Belia Malaysia, M. (2015). Indeks Belia Malaysia 2015. Institut Penyelidikan Pembangunan Belia Malaysia, 2015, $1-96$.

Institut Penyelidikan Pembangunan Belia Malaysia (IYRES). (2016). Penilaian Outcome Indeks Belia Malaysia 2016 (IBM '16) Mengukur Tahap Kualiti \& Kesejahteraan Hidup Belia Malaysia. Retrieved from http://www.ippbm. gov.my/images/ibm/FINAL_IBM2016.pdf

Institute for Youth Research Malaysia (IYRES). (2016). Penilaian Outcome Indeks Belia Malaysia 2016; Mengukur Tahap Kualiti \& Kesejahteraan Hidup Belia Malaysia (Vol. 2016).

Linacre, J. M. (2005). A user's guide to WINSTEPS: Rasch Model Computer Programs. Chicago: MESA Press.

Linacre, J. M. (2007). A User's Guide to WINSTEPS: Ministep Rasch Model Computer Programs. Chicago: MESA Press.

Linacre, J. M. (2012). A user's guide to WINSTEPS: Rasch Model Computer Programs. Chicago: MESA Press.

Ministry of Youth and Sports Malaysia. (2015). Executive Summary: Malaysian Youth Policy. Putrajaya.

Mohd Effendi Ewan Mohd Matore (2019a). Structural Equation Model ( SEM ) in assimilating EQ, SQ and AQ for mechanical students ' context. Proceedings of Mechanical Engineering Research Day 2019, (August), 230-231. Melaka: Universiti Teknikal Malaysia Melaka.

Mohd Effendi Ewan Mohd Matore (2019b). The impact of EQ, SQ and IQ towards AQ using path analysis and Rasch logit for modelling purpose among mechanical engineering students. Proceedings of Mechanical Engineering Research Day 2019, (August), 225-226. Melaka: Universiti Teknikal Malaysia Melaka.

Mohd Effendi Ewan Mohd Matore, \& Ahmad Zamri Khairani. (2018). Comparison of Rasch Model Logits and Likert Mean Score in Testing the Normality Assumption. The Journal of Social Sciences Research, 6(Special Issue), 75-82.

Mohd Effendi Ewan Mohd Matore, Ahmad Zamri Khairani, Siti Mistima Maat, Nor Adila Ahmad, \& Effa Rina Mohd Matore. (2018). The Influence of Intellectual Quotient (IQ), Emotional Quotient (EQ) and Spiritual Quotient (SQ) against Adversity Quotient (AQ) on polytechnic students in Malaysia. Journal of Engineering Science and Technology, Special Is(2018), 83-91.

Nurauliani Jamlus Rafdi, Noor Aimi Mohamad Puad, Wan Shahdila Shah Shahar, Fadilah Mat Nor, \& Wan Shazlinda Shah Shahar. (2015). Faktor-faktor Muflis Di Kalangan Belia. Proceeding of the 2nd International Conference on Management and Muamalah 2015 (2ndICoMM), 2015(November), 484-488.

Reckase, D. (1979). Unifactor latent trait models applied to multifactor tests: Results and implications. Journal of Educational Statistics, 4(3), 207-230. https://doi.org/10.3102/10769986004003207

Rubayah Yakob, Hawati Janor, \& Nur Ain Khamis. (2015). Tahap Literasi Kewangan dalam Kalangan Pelajar Universiti Awam: Kajian di Universiti Kebangsaan Malaysia. Jurnal Personalia Pelajar, 18(1), 98-117.

Stoltz, P. G., \& Weihenmayer, E. (2010). The adversity advantage: turning everyday struggles into everyday greatness (2nd ed.). New York: Fireside.

Vagias, W. M. (2006). Likert-Type Scale Response Anchors (Vol. 7, pp. 1-2). Vol. 7, pp. 1-2. https://doi.org/10.5923/j. economics.20170706.02

Wright, Benjamin D. (1993). "Logits"? Rasch Measurement Transactions, 7(2), 288.

Wright, Benjamin Drake, \& Masters, G. N. (1982). Rating scale analysis Rasch measurement. Chicago: MESA Press. 